\title{
4. COMMISSION DES EPHEMERIDES
}

\author{
Président: M. G. Fayet, Bureau des Longitudes, 3 Rue Mazarine, Paris (6e).
}

Membres: MM. Benitez, Carnera, Clemence, Comrie, Michkovitch, Sadler, Sconzo, Subbotin.

Les circonstances critiques dues à la guerre ont eu pour conséquences, particulièrement en ce qui concerne l'office de la Connaisance des Temps, d'entraver fréquemment la réalisation des calculs asșumés à la suite d'une entente internationale et, en outre, d'empêcher, ou tout au moins de retarder, la communication des résultats aux autres instituts de calcul.

Le volume annuel des positions apparentes des étoiles fondamentales, dont l'office du Nantical Almanac assure la publication depuis I94I, a paru régulièrement. Plusieurs modifications touchant sa confection ont été envisagées; elles ont rapport aux valeurs adoptées pour les Day numbers et aux corrections de parallaxe. Il conviendra sans doute de procéder à une nouvelle répartition des calculs entre les divers offices participants. Il est désirable, d'autre part, que des mesures soient prises afin que cette publication indispensable puisse être mise à la disposition d'un plus grand nombre d'observatoires.

Les offices américain et anglais se sont entendus pour donner prochainement, dans leurs volumes respectifs, des éphémérides précises de Pluton et des quatre principaux astéroïdes Cérès, Pallas, Junon, Vesta.

Les publications aéronautiques annuelles (Air Almanac; American Air Almanac; Éphémérides Aéronautiques) ont profité de nombreuses améliorations et leur forme actuelle peut être considérée comme à peu près définitive.

D'importantes contributions, dues à nos collègues américains et concernant, soit les constantes astronomiques, soit la théorie du Soleil ou des grosses planètes, sont venues accroître d'une manière très appréciable nos connaissances sur ces questions. Les imperfections ou lacunes, que ces recherches ont mises en évidence, ont démontré la nécessité de reconsidérer le problème général du mouvement des planètes principales. Il s'agit d'une œuvre considérable qui exigera une collaboration de grande étendue.

Plusieurs tables fort utiles ont été élaborées et publiées par les soins de l'office du Nautical Almanac.

En complet accord avec mes collègues, MM. Clemence et Sadler, j'estime qu'un changement vraiment utile (et qui devra porter sur l'ensemble) ne pourra être apporté aux constantes astronomiques fondamentales, si l'on n'a pas, au préalable, expliqué d'une façon absolument satisfaisante, les écarts qui existent entre la théorie et l'observation.

Le programme de la prochaine Réunion comporte l'examen des questions suivantes:

\section{Propositions faites par MM. Clemence et Sadler}

I. Questions concerning the volume Apparent Places of Fundamental Stars.

(a) Day Numbers. It is considered desirable that the apparent places should all be based on the same Day Numbers, which could be circulated in advance by the Nautical Almanac Office, as at present. The Office of the American Ephemeris is at present engaged in a new expansion of the nutation including all terms to $0^{\prime \prime}$ ooor, and it is recommended that the Day Numbers A, B, $\mathrm{A}^{\prime}$ and $\mathrm{B}^{\prime}$ should eventually be deduced from the nutation so calculated, including terms to 0.0002 , and published to $0 " 001$.

As regards the aberration it is recommended that the Day Numbers C and D should be computed directly from the motion of the Earth referred to a suitable fixed frame of reference (instead of from multiples of the sine and cosine of the Sun's longitude as at present); it is hoped that specific proposals will be available for discussion at the meeting. It is further recommended that the terms in the aberration depending on the eccentricity of the Earth's orbit should continue to be omitted. 
(b) Parallaxes. The apparent places are corrected for annual parallax only when this is not less than 0 "IOo: it is suggested that it would be more logical to include corrections for parallax in all cases where it is sensible. It will be several years before this can be brought into practice; if adopted, the year r 954 is suggested.

(c) Circumpolar Stars. From time to time suggestions have been made that the number of circumpolar stars is insufficient (Trans. I.A.U. 6, 359 (I938)).

(d) Distribution. There is some evidence that copies of the volume are not reaching all observatories that have a need for it. The British Government pays for the cost of printing and expects to recover part of the cost from the very small sales; free distribution must therefore be limited to one copy to the principal observatory in each country, with a further supply of copies to the Offices contributing to the calculations. If there is, in fact, a shortage of copies due to monetary restrictions it is suggested that the Union might be able to facilitate payment.

2. Questions concerning the Nautical Almanac and other ephemerides.

(a) Number of Apparent Places of Stars. Surveyors have been complaining that the number of stars retained in the Nautical Almanac is insufficient for their purpose, while the separate volume is unnecessary except for geodesists. It is therefore suggested that the number of 200 recommended in the resolution adopted at the Paris meeting as a limit for the number of stars in the ephemerides should be amended to 'about 300 '; the reduced accuracy should be retained, since it is ample for navigators and surveyors.

3. General astronomical questions:

(a) Fundamental Constants. It is our opinion that no change should be made in the system of fundamental astronomical constants until at least some explanation is forthcoming of the discrepancies between theory and observation; and that any change should be introduced as a part of a systematic revision of the whole system.

(b) Distribution of Astronomical Calculations. It is felt that the present distribution of astronomical calculations between the five contributing countries is far from satisfactory, particularly in regard to the apparent places of stars. Apart from other considerations, the Institute of Theoretical Astronomy in Leningrad is at present duplicating the computation of $420 \mathrm{FK}_{3}$ stars. With modern computing equipment the completion of a large routine programme (such as, for instance, the calculation of apparent places of stars) involves little extra work in excess of the planning, preparation and completion of a small programme; centralization would further help to secure that uniformity which is an essential to obtaining the fullest information from the discussion of observations. It would therefore appear that any redistribution should take advantage of this, to enable the routine work to be done more efficiently, and thus to permit the contributing Offices more time for non-routine work. This would appear to be a question which could properly be discussed between the Directors of the National Ephemerides prior to the meeting.

M. le Dr F. Link, de Prague, adresse les propositions suivantes:

Les renseignements fournis par les Ephémérides, relativement aux éclipses de Lune, devraient être complétés et modifiés de la manière qui suit:

I $^{\circ}$ Comporter les instants principaux de l'éclipse avec les angles de position et la grandeur maxima de l'éclipse.

$2^{\circ}$ Les éléments de l'éclipse, qui supposent l'uniformité du mouvement du Soleil, et surtout de la Lune, pendant plusieurs heures, seraient remplacés par un tableau donnant par exemple, de Io en Io $\mathrm{m}$. de temps, la position relative du centre de la Lune au centre de l'ombre, en coordonnées polaires et rectangulaires rapportées à l'équateur. Ces valeurs seraient calculées à partir des positions exactes des deux corps.

$3^{0}$ Le même tableau contiendrait, en intervalles de temps plus espacés, les parallaxes, les rayons du Soleil et de la Lune, ainsi que la libration et l'angle de position de l'axe du dernier corps.

$4^{\circ}$ On donnerait la carte avec les terminateurs de l'ombre calculés comme on vient de l'indiquer. La carte serait complétée par un tableau fixant la position géographique du 
terminateur entier, à l'heure ronde la plus voisine du milieu de l'éclipse. Ce tableau serait disposé d'une façon analogue au tableau IV figurant dans l'article que M. Link a consacré à cette question, dans le Bulletin Astronomique (Tome XIII, fascicule 3).

Voici maintenant les rapports concernant l'activité des divers instituts de calcul chargés de la publication des volumes nationaux d'ephémérides.

\section{Report of the Office of the 'American Ephemeris' to Commission 4, I.A.U.}

This Report covers the years I938-47, inclusive. A. J. Robertson retired in I940 and was succeeded as director by W. J. Eckert, who resigned in 1945 and was succeeded by G. M. Clemence.

The following changes have occurred in the construction of the American Ephemeris and Nautical Almanac, in addition to those mentioned in the I938 report. From I94I onwards the authority for the places of fundamental stars is the $\mathrm{FK}_{3}$, and the authority for the places of stars occulted by the Moon is the Catalogue of 3539 Zodiacal Stars for the Equinox I950.0, Astr. Papers Amer. Eph. Vol. ro, pt. II. From I942 the angular distance of the Moon from the Sun is given to the nearest minute of arc, twice daily. From I 948 the ephemerides of Jupiter's satellites VI and VII are based on improved elements; and occultation predictions for a fifth station in the U.S.A. are included. The Introduction was rewritten in the volume for I944 in order to remove some ambiguities and to correct some erroneous statements. Where disagreement exists between the Introductions in the volumes for 1944 and I943, the Introduction is correct in the volume for I 944 and incorrect in 1943 and some preceding years, but it has not been possible in all instances to determine the exact year when a statement in the Introduction ceased to be true; the Office will make a specific investigation of any specific matter on request. The most serious example is the statement that the nutation used in computing the ephemerides of the Sun, Moon, and planets is taken from Newcomb's tables of the Sun, which has not been done since about I9I8.

Emergencies resulting from the war in Europe prevented or delayed the fulfilment of the international exchange agreements in some cases. In consequence, the conjunctions, phenomena, and configurations of Jupiter's satellites I-IV, customarily supplied by the Office of the Connaissance des Temps, were computed here for the years I945, I946, and I947; this was also the case with the apparent places of 32 circumpolar stars for the years I $942-47$, inclusive. The apparent places of 166 ro-day stars, customarily supplied by the Office of the Berliner Jahrbuch, were computed here for I948, as have been the mean places of 1535 stars for the years $195 \mathrm{I}-60$, inclusive. It should be mentioned that some of this work proved to be duplication which might have been avoided if prompt communication had been possible.

The following changes will be made in the American Ephemeris and Nautical Almanac for I95I. The Washington transit ephemeris of the Sun, Moon, and planets will be omitted. The equatorial rectangular co-ordinates of the Sun will be given at intervals of $I$ day, and the reduction to the true equinox of date will be omitted. The occultation data will be extended to include stars to magnitude 7.54 , and the apparent places of occulted stars will be given. Tables $A$ and $B$ will be omitted as being no longer useful. The list of mean places of fundamental stars will be extended to include about I55O stars for the convenience of users who desire spectral types and approximate positions of more stars than are now given.

Under a co-operative agreement with the Office of the Nautical Almanac, a precise ephemeris of Pluto will be given in the American Ephemeris and Nautical Almanac beginning with I950 or I95I; and precise ephemerides of Ceres, Pallas, Juno, and Vesta as soon as possible, probably I95I or I952. Heliocentric positions of Pluto to I96o have been obtained by numerical integration. For the four asteroids use is being made of approximate integration orbits supplied by the Yale Observatory and the Cincinnati 
Observatory. These are being corrected and the numerical integration of the definitive orbits will be undertaken by the Cincinnati Observatory.

The American Air Almanac has been published in three volumes a year beginning I94I, with little change in content or arrangement. The introduction of automatic methods of preparation and proof reading has resulted in a standard of accuracy never hitherto attained in a similar publication. The calculations are performed by means of punched cards, which are then used to control a special card-operated typewriter. Plates for printing the book are obtained photographically from the typewritten copy. New punched cards are prepared from the proofs, and these cards are compared by machine with the cards that actuated the typewriter. This method has so far been used for the publication of nearly $20,000,000$ separate figures, without a known error. Similar methods will be used for the American Nautical Almanac from I950.

The introduction of punched-card methods of computing has resulted in significant economy and appreciable gains in reliability. More than two-thirds of the routine work of the Office has been adapted to these methods.

Supplements to the American Ephemeris and Nautical Almanac were issued for the total solar eclipses of I940 October I, I945 July 9, and 1947 May 20. Another supplement, entitled Tables of Sunrise, Sunset, and Twilight, gives the time of sunrise and sunset for every day of the year and for every degree of latitude from the equator to $75^{\circ}$ North. The durations of daylight and civil, nautical, and astronomical twilight are given at 2-day intervals. Charts extend these data to the pole; and auxiliary tables extend them to every place on earth throughout the present century.

The apparent places of 162 Io-day stars have been supplied annually for the volume Apparent Places of Fundamental Stars.

The apparent places of star-pairs for the use of the International Latitude Service in the years I947, 1948, and 1949 on their northern and southern parallels have been calculated and supplied to the Joint Latitude Commission, by special arrangement with its President, as a result of the emergency occasioned by the war.

The manuscript for Kleine Planeten for 1946, received from Prof. Kopff, was reproduced photographically and distributed. Further information on this publication will be found in the report of Commission 20.

A number of contributions have increased our knowledge of motions in the solar system and of the constants of astronomy since I938. Extensive discussions of observations of the Sun have been made by H. R. Morgan and F. P. Scott, and of Mercury by Clemence. These have led to improved knowledge of the mass of Venus and the mass of the Moon, and have confirmed Spencer Jones's result that the fluctuations in the mean longitudes of the Sun, Moon, and planets are proportional to their mean motions. The relativity effect in the motion of Mercury is precisely confirmed, and the effect in the motion of the Earth has been detected. Observations of Uranus and Neptune have been extensively discussed by L. R. Wylie, and compared with Newcomb's tables. The orbits of these planets from $I 780$ to I950 have been obtained by numerical integration and compared with Newcomb's tables by Brouwer, and with observations through Wylie's discussion. In the case of Neptune the numerical integration confirms Newcomb's theory in general, the principal discordance being in the coefficient of the synodic term produced by the action of Jupiter. In the case of Uranus it appears that the numerical integration is not in complete agreement with either the observations or the theory. Appreciable deficiencies in Newcomb's theory are indicated. The work of Brouwer and of Wylie has resulted in a good determination of the mass of Pluto. The solar theories of Newcomb and Leverrier have been compared by K. P. Williams. Clemence and Scott have shown that appreciable inadequacies exist in Newcomb's theory of Mars, of a sort that vitiate the determination of the mass of Venus from its action on Mars. A new determination of the constant of nutation has been made by Morgan.

The defects in existing theories just mentioned, as well as other known inadequacies, indicate that a new attack on the whole problem of the motions of the principal planets is needed. In view of the tremendous mass of observational material accumulated since 
Newcomb's time, and of the extensive theoretical and computational work needed to utilize it and to improve the form of the theory, it is evident that a concerted effort is necessary. Accordingly, early in I947, a joint enterprise was undertaken by the Yale Observatory, the Watson Scientific Computing Laboratory, and this Office, with support for two years assured by the Office of Naval Research. Work is now proceding at these three institutions along several lines simultaneously.

As a first step in the improvement of the general theories, an experimental development is being carried out on the motions of Jupiter and Saturn with the purpose of determining whether it is practicable with modern techniques of calculation to develop these theories with the same degree of perfection as the lunar theory, that is, to express the co-ordinates as sums of strictly periodic functions of the time. The analytic developments have been completed and the first approximation in the numerical work is about half finished.

With the object of improving the mass of Saturn a discussion of photographic observations of the satellites is in progress. A conventional theory of the motion of Mars by Hansen's method is being constructed; and also a new development of the theory of precession and nutation, which will extend Oppolzer's work on the subject to a higher order of accuracy. It is intended shortly to undertake a discussion of observations of Venus to improve the mass of Mercury, and of Jupiter to improve the mass of Saturn. The secular perturbations of Pluto will be determined by a method similar to that used by Brouwer for Encke's comet. Preliminary work on a new fundamental star catalogue is in progress.

Among the results to be expected is a determination of the constant of precession with a precision comparable to that obtained by analysis of stellar proper motions.

An examination of the entire system of astronomical constants is in progress with the object of determining whether it is yet possible to introduce a perfectly consistent system which would not be contradicted by observations, and if so, to determine what corrections to the lunar, solar, and planetary tables would be necessary.

G. M. Clemence

\section{Report of the (British) Nautical Almanac Office to Commission 4 of the INTERNATIONAL ASTRONOMICAL UNION}

This Report covers the period since the 1938 Stockholm meeting, i.e. the years $1938-47$ inclusive.

As indicated in the 1938 report the Nautical Almanac for I94I conformed to the resolutions passed at the Paris meeting relating to the publication of a separate volume of apparent places of stars; since then the authority for the fundamental stars is the $\mathrm{FK}_{3}$, and that for occulted stars the New Zodiacal Catalogue.

Considerable changes were made in the edition for I942, when many sections were omitted, including the Occultation Reduction Elements; these were subsequently published for I 942 by the American Section of the Union. From I943 onwards, it was decided to stop the computation of these Elements and, in lieu, to undertake the reduction of all observed occultations; at the same time it was agreed to undertake responsibility for the annual compilation and discussion previously done by Prof. Brouwer. The discussion for I 943 is in course of publication; the work of reduction is still considerably behind schedule, but it is hoped that the whole occultation programme will shortly be brought up to date. It is intended to publish all observations received, properly reduced, in one central list in the Greenwich Observatory publications, whether or not they have been previously published elsewhere. The programme of predictions, somewhat restricted during the war, is now being continued at its former level with minor modifications.

Many detailed changes have been made in the Nautical Almanac, and these are listed, as they occur, in the Preface to each edition. The stress of war and its aftermath has so far made it impossible to publish the Supplement, promised in the Preface to the edition for 1942 , which is to contain all the permanent tables and explanations, previously given in the Almanac itself, together with such added information as can be conveniently 
included in the wider scope of a separate publication; in particular, it will contain a summary of the authorities for the data in the Nautical Almanac since the first edition of $\mathrm{I} 767$.

It has not been possible to advance the date of publication of the Nautical Almanac in accordance with the intention reported at the I938 meeting, and with the resolution then adopted. Vigorous steps are now being taken to expedite publication and to make the Almanac available sufficiently early for the preparation of the minor 'annuaires'. However, the first part of the Nautical Almanac, containing the fundamental ephemerides of the Sun, Moon and planets, is now circulated three years in advance to the principal observatory in each country. In co-operation with the Office of the American Ephemeris, an astrometric ephemeris of Pluto will be introduced into the Almanac from I95I (or 1950) onwards, while ephemerides of Ceres, Pallas, Juno and Vesta will be included as soon as possible. Other projected changes include the gradual introduction of U.T, as an alternative terminology to G.M.T.

The first edition of Apparent Places of Fundamental Stars was issued in r940 for the year $\mathrm{rg4I}$; it has been published annually since then, the scheduled date of publication being April in the year preceding. It contains the apparent places of I483 Io-day and 52 circumpolar stars, based on the $\mathrm{FK}_{3}$ (and its supplement). Its form follows, with but minor amendments, that discussed and agreed at the I938 meeting of the Union. Difficulties of communication during the war led to temporary redistributions of the calculations; for the years $1942-46$, the Nautical Almanac Office computed the apparent places of the 426 stars normally contributed by the Office of the Connaissance des Temps. As regards the mean places, it has been decided to print and circulate these to the contributing almanac offices, for each year, in time to serve as a basis for the calculation of the apparent places; for I948-50 they were computed by the Nautical Almanac Office, and for I95I and 1952 are based on the calculations made by the Office of the American Ephemeris. Now that similar data are available from the Astronomisches RechenInstitut at Heidelberg a decision as to the authority to be adopted for I953 onwards will shortly be required. Various other questions regarding the content and distribution of the volume are being brought forward for discussion at the Zürich meeting.

The second volume of Planetary Co-ordinates for the Equinox I950.0 covering the years I940-60 was published in September I939; the distribution was consequently interrupted, though every effort was made to send copies through those channels that were open. During I940, the type, plates and stock for this publication were destroyed (as well as much material for the Nautical Almanac itself) leaving only a very small number of copies at the disposal of the Office, for meeting essential astronomical requirements by loan. A photographic reprint is now available.

The navigational work of the Office has been greatly increased, in many directions, not all concerned with astronomical navigation. The Air Almanac was redesigned a second time in I944, and continues to be published in what may now be regarded as an essentially permanent form.

The fifteen volumes of Astronomical Navigation Tables covering latitudes S. $69^{\circ}$ to N. $79^{\circ}$ originally prepared for use by the Royal Air Force, are now generally available; their general content and arrangement were described in the report of the Stockholm meeting. A final volume covering latitudes N. $80^{\circ}$ to $89^{\circ}$ is under consideration. The Abridged Nautical Almanac, which has remained essentially unchanged since I929, is being revised, while consideration is being given to the preparation of new tables for the reduction of astronomical observations at sea.

At a recent conference of surveyors a requirement was put forward for a separate Surveyor's Almanac and this project is at present being examined; the main requirement is for the positions of a large number of stars to a small degree of accuracy. Neither the almanac for surface navigation nor the volume of apparent places fulfils the requirements.

Various tables have been prepared and published. The Tables of Depression and Azimuth of the Sun for latitudes N. $45^{\circ}$ to $60^{\circ}$ were issued in I945, giving depressions to $0^{\circ} \cdot I$ at a small interval of time. The Seven-figure Trigonometrical Tables for every second of time, 
mentioned in the previous report, was published in August 1939. No publisher has yet been found for the 7 -figure table prepared by the late Prof. Peters and Dr Comrie, and it has not been possible to implement the resolution regarding these tables adopted by the Union in I938. The corresponding 8-figure table was published in Germany during I939 and has since been photographically reproduced both in Britain and U.S.A. During the war, the Office had occasion to produce, for special purposes, two five-figure tables: Five-Figure Logarithm Tables is merely a reprint of three existing tables conveniently bound together; the argument for the trigonometrical functions is in degrees and decimals; Five-Figure Tables of Natural Trigonometrical Functions has the argument in degrees, minutes and seconds, with an interval of $10^{\prime \prime}\left(I^{\prime \prime}\right.$ for the cotangent to $\left.7^{\circ} 30^{\prime}\right)$.

Since 1938 , the Office has done no fundamental astronomical work.

\section{Bureau des Longitudes (Paris)}

Lorsque furent définitivement arrêtées les modalités concernant la publication du volume international Apparent Places of Fundamental Stars, la Connaissance des Temps se chargea de calculer annuellement 426 étoiles de Io en Io jours et 32 circompolaires.

Les grandes difficultés résultant de la guerre n'ont pas permis, durant cette période, d'assurer régulièrement la collaboration convenue: certains calculs n'ont pu être effectués et les résultats, portant sur d'autres, n'ont pu être transmis en temps utile à l'office du Nautical Almanac, qui assure l'impression.

La publication de la Connaissance des Temps elle-même a subi des retards considérables, que nous nous sommes efforcés de rattraper peu à peu, malgré le nombre restreint de nos calculateurs et le manque de machines à calculer: on escompte que le volume de I949 pourra paraître avant la fin de I948.

Notre office a assumé, d'autre part, la tâche de calculer et publier, d'après les Tables de R.-A. Sampson, des éphémérides détaillées pour les quatre premiers satellites de Jupiter. Ce travail a toujours été réalisé, mais à plusieurs reprises, pendant la guerre, nous n'avons pu faire parvenir les résultats aux offices anglais et américain.

La publication annuelle du volume des Ephémérides Aéronautiques, commencée en I935, a été poursuivie régulièrement. D'assez nombreuses modifications, dont voici un résumé des principales, ont été apportées depuis r938, à la forme primitive.

Dans les feuilles quotidiennes relatives au Soleil, aux grosses planètes et à la Lune, on ne donne plus l'ascension droite verse, mais l'angle horaire du méridien de Greenwich. L'intervalle de temps universel, argument de ces feuilles, a été ramené de 20 minutes à ro minutes. La correction de parallaxe, qui doit être appliquée aux hauteurs lunaires, est fournie maintenant, pour chaque jour, en marge de toutes les feuilles quotidiennes, sous la forme d'un tableau où l'argument est la hauteur.

Depuis I947, en raison des difficultés d'impression, l'ouvrage est édité en fascicules; à la fin de chacun d'eux se trouvent des tables dont quelques-unes figuraient auparavant dans l'annexe. Je signale les tables nouvelles qui, sous une forme condensée, permettent d'obtenir les heures du lever et du coucher du bord supérieur du Soleil et de la Lune, en un point quelconque situé à l'altitude zéro, entre les latitudes $0^{\circ}$ et $\pm 67^{\circ}$. Enfin, un petit tableau, ajouté récemment, fournit la correction de Coriolis, en fonction de la vitesse et de la latitude.

\section{Instituto y Observatorio de Marina, San Fernando, Espagne (M. W. Benitez)}

Conformément aux conventions arrêtées au Congrès International des Ephémérides tenu à Paris, en octobre I9II, l'office calcule les positions moyennes et les positions apparentes, de ro en Io jours, de 396 étoiles non circompolaires dont 377 figurent dans la publication internationale Apparent Places of Fundamental Stars, ainsi qu'il en a été décidé lors de la Réunion de l'U.A.I., en I932.

G. FAYET

Président de la Commission 
Report of meeting. I0.30 a.m. on Thursday, August I2, I948.

President: Dr Fayet.

SECRETARY: Prof. KopfF.

With Dr Fayet in the chair there were present the following members: MM. Benitez, Clemence, Comrie, Sadler, Sconzo. M. Kopff was present by invitation.

M. Kopff was appointed as secretary and interpreter to the Commission.

M. Fayet read the two resolutions of the General Assembly that had been referred to Commission 4; he proposed that only the first should be considered at the present meeting, namely:

'Que l'Union se charge de donner une définition plus exacte de l'unité de temps.'

After discussion the following recommendation, proposed by Dr Clemence, was adopted for consideration by Commission $3 \mathrm{I}$ and, if agreed, then for submission to the General Assembly:

'It is recommended that when it is desired to adopt an invariable unit of time with the greatest possible exactitude, the mean solar second for Igoo January I Greenwich Mean Noon should be used.'

The Commission then proceeded to discuss the proposals made by MM. Clemence and Sadler in the Report concerning the volume Apparent Places of Fundamental Stars (p. 75).

It was agreed to adopt the Day Numbers as proposed in I $(a)$, subject to the condition that they will not be used for the calculation of apparent places of fundamental stars before 1956 .

The Commission agreed to include corrections for annual parallax for certain stars even when this is less than $o^{\prime \prime} \cdot x 00$, the details to be arranged and circulated by M. Sadler, if possible in time for introduction for I954.

No action was considered to be necessary as regards $(c)$, the provision of a greater number of circumpolar stars.

Second meeting. The Commission held its second meeting at II.30 a.m. on August r4, I948. M. Fayet referred to the proposals by Dr Link relative to lunar eclipses (see p. 76) and stated that Dr Link wished to calculate and publish the data without cost to the Union. It was resolved that:

'La Commission appuie très favorablement le projet formé par l'Observatoire National de Prague, de publier annuellement un Supplément international fournissant des données détaillées concernant les éclipses de lune et les occultations d'étoiles faibles pendant ces éclipses.'

Discussion then took place on the number of stars for which apparent places should be given in the national ephemerides. MM. Kopff and Sadler outlined the plans for the publication of an 'Astronomisch-Geodaetisches Jahrbuch' and a 'Star Almanac', specially designed for surveyors. It was generally agreed to select the limit of 200 suggested in the resolution at the Paris (I935) meeting.

On the question of the revision of the system of fundamental constants, Dr Jackson informed the Commission that the Nominating Committee was appointing a special sub-commission of Commission 4 on this subject; it was agreed to take no further action at this stage. M. Fayet stated that he found it increasingly difficult to calculate the apparent places of all the Io-day stars for which the Office of the 'Connaissance des Temps' was responsible. He suggested that some at least might be taken over by the Institute for Theoretical Astronomy in Leningrad. M. Sadler was of the opinion that it was too soon to enter into any formal agreement, but suggested that the (British) Nautical Almanac Office, which is responsible for the publication, should also accept responsibility for the calculation of these stars as well; he would make informal arrangements for the actual calculations with Dr Subbotin at Leningrad and Dr Hagihara in Tokyo, with a view to formal confirmation at the I95I meeting of the Union. M. Mikhailov indicated his agreement to this suggestion, which was generally approved. 
In the discussion Prof. Banachiewicz remarked that a preliminary suggestion had been made for an international astronomical computing organization.

The President opened discussion on the following resolution referred to the Commission by the General Assembly:

'Que l'U.A.I. considère de nouveau la résolution prise au congrès de I928 sur la désignation du temps civil de Greenwich, donne à cette résolution une rédaction plus nette, et lui donne la publicité nécessaire pour la faire admettre universellement.'

Both M. Clemence and M. Sadler stated that there were considerable difficulties in the introduction of the terminology U.T. into the navigational almanacs. After discussion it was agreed to recommend the following resolution to the General Assembly:

"La Commission recommande que la désignation "Temps Universel" (Universal Time, Weltzeit) soit seule utilisée par les astronomes pour désigner le temps solaire moyen, compté à partir de minuit au méridien de Greenwich.

'Elle exprime le vœu que cette désignation remplace aussitôt que possible les autres expressions encore employées.'

Third meeting. The third meeting of the Commission was held on August I6, I948, at Io.30 a.m.

M. Clemence recalled that the Executive Committee referred a question concerning the unit of time to Commissions 4 and $3 \mathrm{I}$, and that at the first meeting a resolution on the subject was passed to be referred to Commission $3 \mathrm{I}$. Commission $3 \mathrm{I}$ has not passed this resolution but $M$. Danjon has stated that he does not regard action on this matter as urgent. M. Clemence accordingly proposed that Commission 4 should withdraw its resolution on the unit of time, with the intention of dealing with the matter when the whole subject of the system of astronomical constants is discussed in I95I; the sub-commission of Commission 4 would doubtless discuss the question.

M. Kepinski proposed that two pages of the national Almanacs should be devoted to the barycentric co-ordinates of the Sun referred to the equinox of the beginning of the current year. It was agreed that, as these co-ordinates depend on the masses of the planets, it would be desirable to defer the introduction of this ephemeris until improved masses are available as a result of the forthcoming revision of the system of fundamental constants.

M. Mikhailov presented a report of the work done by the Institute for Theoretical Astronomy in Leningrad: he referred to the fact that until I948 the Institute had performed all the calculations for the 'Annuaire Astronomique de l'U.R.S.S.', but that from I948 onwards material had been exchanged with the British Nautical Almanac Office. $\mathrm{He}$ gave details of the calculations to be undertaken in the future. It was agreed that the Commission thank the Institute for Theoretical Astronomy for its offer of collaboration and that the Directors of the several almanac offices be authorized to arrange among themselves the details of the collaboration, during the next few months.

M. Clemence showed a specimen copy of the new (G.H.A.) form of the American Nautical Almanac and MM. Fayet and Sadler stated that both the French and British almanacs for surface navigation were undergoing revision.

M. Sadler informed the Commission that a request had been received from Commission 20 for the accepted Io-day dates (midnights of which have the integral parts of the Julian Day Number multiples of Io) to be distinguished (by asterisks, special type or in other ways) in the ephemerides of the Sun's equatorial rectangular co-ordinates, particularly those referred to the equinox of I950.0. The Directors of the national ephemerides agreed to make the necessary arrangements for this to be done.

M. Sadler informed the rneeting that satisfactory arrangements had been made between M. Clemence and Prof. Kopff for the calculation of the mean places of the $\mathrm{FK}_{3}$ stars (see p. 8o).

M. Fayet then declared the meeting closed and thanked the members of the Commission for their attendance. 